\title{
Dipole Moment Studies. VII. Dipole Moments of the Halofluorophosphines
}

\author{
Joseph G. Morse* and R. W. Parry $\dagger$ \\ Department of Chemistry, University of Michigan, Ann Arbor, Michigan 48104
}

(Received 21 April 1972)

\begin{abstract}
Dipole moment measurements have been made on a series of halophosphines using gas phase heterodyne beat methods. Values obtained are: $\mathrm{PF}_{3}, 1.00 \pm 0.03 \mathrm{D} ; \mathrm{PF}_{2} \mathrm{Cl}, 0.93 \pm 0.01 \mathrm{D} ; \mathrm{PFCl}_{2}, 0.86 \pm 0.05 \mathrm{D} ; \mathrm{PF}_{2} \mathrm{Br}_{\text {, }}$ $0.83 \pm 0.05 \mathrm{D}$; and $\mathrm{PF}_{2} \mathrm{I}, 0.85 \pm 0.06 \mathrm{D}$. The value for $\mathrm{PF}_{3}$ is in reasonable agreement with the microwave value [R. G. Schulman et al., Phys. Rev. 78, 145 (1950)], of $1.025 \pm 0.009$ D. Molecular moments for the mixed halophosphines are approximated reasonably well by the vector sum of $\mathrm{P}-\mathrm{X}$ moments, but the value for $\mathrm{PF}_{2} \mathrm{H}$ cannot be estimated in this way. An explanation is offered in terms of a polarization model.
\end{abstract}

In previous papers of this series ${ }^{1}$ the best available dipole moment values for alkylphosphines, alkylamines, alkylphosphineboranes, and alkylamineboranes were reported. The results of these studies were satisfactorily rationalized in terms of a polarization model in which a lone pair moment for nitrogen was identified and $P-R$ bond moments were varied systematically in order to compensate for changes in the polarizability of phosphorus as alkyl groups replaced hydrogen. The present study was initiated in order to determine whether the same kinds of variations were indicated in a similar series of halophosphines. One would anticipate that changing one halogen for another would have a smaller effect on phosphorus polarizability than would replacing a hydrogen atom by an alkyl group. If this is true, the concept of bond additivity would be more reliable than would be true when hydrogen is bound to phosphorus. Another factor noted in the alkylphosphine studies was the role of the inductive effect of the $R$ group on the P-R moment. This concept would also be applicable here. Two series were considered. The first was $\mathrm{F}_{3} \mathrm{P}, \mathrm{F}_{2} \mathrm{PCl}, \mathrm{FPCl}_{2}, \mathrm{PCl}_{3}$. The second was the series $\mathrm{F}_{3} \mathrm{P}, \mathrm{F}_{2} \mathrm{PCl}, \mathrm{F}_{2} \mathrm{PBr}, \mathrm{F}_{2} \mathrm{PI}$. Of these compounds the dipole moments for the mixed halophosphines had not been determined previously. In addition $\mathrm{PF}_{3}$ was reinvestigated to check our measurements against a previously reported microwave value. ${ }^{2}$

\section{RESULTS}

The dipole moments were obtained by the standard Debye method and are recorded in Table I, along with literature values for the unsubstituted trihalophosphines. The relatively large standard error limits for $\mathrm{PF}_{2} \mathrm{I}$ and $\mathrm{PFCl}_{2}$ reflect their limited volatility and tendency toward disproportionation. In making the measurements, particular care was taken, especially with $\mathrm{PF}_{2} \mathrm{I}$, to assure the purity of the sample at all states of the measurement. It was frequently redistilled and its purity checked by infrared spectroscopy.

The overall molecular moments were resolved into bond moments using the procedures described earlier. ${ }^{1}$ It was assumed that the phosphorus lone pair moment was zero and that bond angles had values as shown in the literature ${ }^{8}$; for $\mathrm{PF}_{3}, \mathrm{FPF}=98.2^{\circ}$; for $\mathrm{PCl}_{3}, \mathrm{ClPCl}=$ $100^{\circ}$; for $\mathrm{PBr}_{3}, \mathrm{BrPBr}=101^{\circ}$; and for $\mathrm{PI}_{3}, \mathrm{IPI}=100^{\circ}$ The bond moments were obtained by considering the $\mathrm{PX}_{3}$ molecular dipole moment as a resultant of three equivalent $\mathrm{P}-\mathrm{X}$ vectors acting at the angles given above. In carrying out the vector addition of bond moments to obtain molecular moments for $\mathrm{PX}_{2} \mathrm{Y}$, the following angles were used: $F P F=98^{\circ}, F P X=100^{\circ}, X P X=100^{\circ}$. Changes of $1-2^{\circ}$ in these values give changes of about

TABLE I. Dipole moments of halophosphines.

\begin{tabular}{|c|c|c|c|}
\hline Sample & $\begin{array}{c}\text { Molecular } \\
\mu \text { (observed) } \\
\text { (debyes) }\end{array}$ & $\begin{array}{c}\text { Bond } \mu \mathrm{P}-\mathrm{X} \\
\text { (calculated) } \\
\text { (debyes) }\end{array}$ & $\begin{array}{c}\text { Molecular }^{\mathrm{a}} \\
\mu(\text { calculated }) \\
\text { (debyes) }\end{array}$ \\
\hline $\mathbf{P F}_{3}$ & $\begin{array}{l}1.00 \pm 0.03 \\
1.025 \pm 0.009 \mathrm{~b}\end{array}$ & 0.70 & $\cdots$ \\
\hline $\mathrm{PF}_{2} \mathrm{Cl}$ & $\begin{array}{l}0.93 \pm 0.01 \\
0.890 \pm 0.010^{\circ}\end{array}$ & & 0.94 \\
\hline $\mathrm{PFCl}_{2}$ & $0.86 \pm 0.05$ & & 0.90 \\
\hline $\mathrm{PCl}_{3}$ & $0.78 \pm 0.01^{d}$ & 0.57 & $\cdots$ \\
\hline $\mathrm{PF}_{2} \mathrm{Br}$ & $0.83 \pm 0.05$ & & 0.89 \\
\hline $\mathbf{P B r}_{3}$ & $0.52+?^{e}$ & 0.37 & \\
\hline $\mathrm{PF}_{2} \mathrm{I}$ & $0.85 \pm 0.05$ & & 0.92 \\
\hline $\mathrm{PI}_{3}$ & $0.00 \pm ?^{f}$ & 0.00 & \\
\hline $\mathrm{PF}_{2} \mathrm{H}$ & $1.35 \pm 0.02 \mathrm{x}$ & & 1.09 \\
\hline
\end{tabular}

a Calculated as vector sum of bond moments.

b Reference 2 .

c Reference 3.

d Reference 4.

e Reference 5.

f Reference 6.

s Reference 7.

$0.02 \mathrm{D}$ in the resultant molecular moment. Bond moments are listed in Table I.

\section{DISCUSSION}

Inspection of the results given in Table I shows that in every case the simple vector sum of the bond moments falls close to the experimental error limit range. As anticipated, changes of one halogen atom for another seem to have less effect on the polarizability of phos- 
TABLE II. Experimental values for determination of dipole moments of gaseous halophosphines.

\begin{tabular}{|c|c|c|c|c|c|c|c|c|}
\hline & $T\left({ }^{\circ} \mathrm{K}\right)$ & $\begin{array}{c}(\Delta C / \Delta P)_{\mathrm{P}=0} \\
(\mathrm{pF} / \mathrm{mm}) \times 10^{3}\end{array}$ & $\begin{array}{c}\left(P_{T}\right) \\
\mathrm{cc}\end{array}$ & & & $T\left({ }^{\circ} \mathrm{K}\right)$ & $\begin{array}{r}(\Delta C / \Delta P)_{\mathrm{P}=\mathrm{o}} \\
(\mathrm{pF} / \mathrm{mm}) \times 10^{3}\end{array}$ & cc \\
\hline \multirow[t]{8}{*}{$\mathrm{PF}_{3}$} & 300.29 & 1.161 & 33.97 & & \multirow[t]{7}{*}{$\mathrm{PF}_{2} \mathrm{I}$} & 298.86 & 1.500 & 43.68 \\
\hline & 292.03 & 1.200 & 34.15 & . & & 290.29 & 1.560 & 44.13 \\
\hline & 281.78 & 1.289 & 35.39 & & & 281.19 & 1.597 & 43.76 \\
\hline & 273.11 & 1.360 & 36.19 & & & 274.31 & 1.665 & 44.51 \\
\hline & 262.97 & 1.440 & 36.90 & & & 267.10 & 1.745 & 45.42 \\
\hline & 249.90 & 1.564 & 38.09 & & & 260.02 & 1.810 & 45.86 \\
\hline & 245.30 & 1.600 & 38.25 & & & & & \\
\hline & \multicolumn{5}{|c|}{$P_{T}=(13.7 \pm 1.2)+(6080 \pm 336) / T$} & \multicolumn{3}{|c|}{$P_{T}=(28.7 \pm 3.5)+(4406 \pm 971) / T$} \\
\hline \multirow[t]{7}{*}{$\mathrm{PF}_{2} \mathrm{Cl}$} & 298.96 & 1.209 & 35.21 & & \multirow[t]{6}{*}{$\mathrm{PFCl}_{2}$} & 303.44 & 1.206 & 35.66 \\
\hline & 287.68 & 1.278 & 35.84 & & & 292.38 & 1.268 & 36.17 \\
\hline & 277.54 & 1.351 & 36.53 & & & 282.99 & 1.354 & 37.34 \\
\hline & 267.87 & 1.427 & 37.25 & & & 273.86 & 1.402 & 37.42 \\
\hline & 258.61 & 1.500 & 37.80 & & & 265.05 & 1.471 & 38.00 \\
\hline & 250.19 & 1.587 & 38.70 & & & 256.59 & 1.532 & 38.32 \\
\hline & \multicolumn{5}{|c|}{$P_{T}=(17.5 \pm 0.5)+(5275 \pm 146) / T$} & \multicolumn{3}{|c|}{$P_{T}=(21.0 \pm 2.0)+(4494 \pm 548) / T$} \\
\hline \multirow[t]{7}{*}{$\mathrm{PF}_{2} \mathrm{Br}$} & 298.94 & 1.328 & 38.67 & & & & & \\
\hline & 287.88 & 1.404 & 39.40 & & & & & \\
\hline & 277.39 & 1.494 & 40.37 & & & & & \\
\hline & 267.60 & 1.542 & 40.21 & & & & & \\
\hline & 258.74 & 1.627 & 41.02 & & & & & \\
\hline & 250.05 & 1.707 & 41.06 & & & & & \\
\hline & \multicolumn{8}{|c|}{$P_{T}=(24.7 \pm 1.8)+(4424 \pm 500) / T$} \\
\hline
\end{tabular}

phorus than does the replacement of a hydrogen atom by an alkyl group. Data are consistent with chemical prejudices which indicate that the phosphorus atom should be the positive member in the $\mathrm{P}-\mathrm{X}$ linkage.

While vector addition gives fairly reasonable values for the halophosphines, it is significant that bond moment addition does not reproduce the result for $\mathrm{HPF}_{2}$. The calculated value is $1.09 \mathrm{D}$; the measured value is $1.35 \mathrm{D}$. Clearly the $\mathrm{P}-\mathrm{F}$ bond moment is somewhat larger in $\mathrm{HPF}_{2}$ than in $\mathrm{PF}_{3}$. A reasonable explanation can be obtained from a vector diagram. In $\mathrm{PF}_{3}$ the positive phosphorus atom is symmetrically placed above three negative fluorine atoms to give the following pattern:

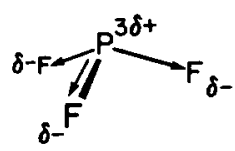

In $\mathrm{HPF}_{2}$ the most logical assumption makes $\mathrm{H}$ positive with respect to the phosphorus and fluorine negative with respect to phosphorus. Because the angle between the F-P-F resultant and the $\mathrm{P}-\mathrm{H}$ vector is nearly $90^{\circ}$ the calculated molecular moment for $\mathrm{PF}_{2} \mathrm{H}$ is independent of the assumption as to the polarity or direction of the $\mathrm{P}-\mathrm{H}$ vector.<smiles>F[PbH2]P(F)(F)(F)F</smiles>

Increased electron density on phosphorus resulting from the $\mathrm{H}-\mathrm{P}$ vector would permit negative charge movement toward the fluorine atoms thus increasing the magnitude of the $\mathrm{P}-\mathrm{F}$ vector, a result consistent with the observed values.

As electronegativity arguments would indicate, the $\mathrm{P}-\mathrm{X}$ moment decreases in the series where $\mathrm{X}=\mathrm{F}, \mathrm{Cl}$, $\mathrm{Br}, \mathrm{I}$, but no quantitative correlation with electronegativity seems justified. ${ }^{9}$ In fact that the molecular moment for $\mathrm{PF}_{2} \mathrm{I}$ is greater than that for $\mathrm{PF}_{2} \mathrm{Br}$ may seem to be in conflict with the foregoing statement on bond moments. This is not a point of conflict. The pyramidal geometry of the molecules is such that addition of the resultant of the two P-F moments and the negligible $\mathrm{P}-\mathrm{I}$ moment gives a value equal to or 
very slightly larger than addition of the $\mathrm{P}-\mathrm{F}_{2}$ resultant and the larger $\mathrm{P}-\mathrm{Br}$ moment.

\section{EXPERIMENTAL}

\section{Materials}

Difluorophosphines were prepared according to the literature. ${ }^{10,11} \mathrm{Cl}_{2} \mathrm{PF}$ was prepared in the same manner from $\left[\left(\mathrm{CH}_{3}\right)_{2} \mathrm{~N}\right]_{2} \mathrm{PF}^{12}$ and $\mathrm{HCl}$ by the reaction

$$
\left[\left(\mathrm{CH}_{3}\right)_{2} \mathrm{~N}\right]_{2} \mathrm{PF}+4 \mathrm{HCl} \rightarrow 2\left(\mathrm{CH}_{2}\right)_{2} \mathrm{NH}_{2} \mathrm{Cl}+\mathrm{PFCl}_{2} \text {. }
$$

The white solid product was identified as $\left(\mathrm{CH}_{3}\right)_{2} \mathrm{NH}_{2} \mathrm{Cl}$ by its $\mathrm{x}$-ray powder pattern. The $\mathrm{PFCl}_{2}$, trapped through vacuum distillation at $126^{\circ} \mathrm{C}$, was identified by its vapor density molecular weight: Calc 120.9, Found 118; and its infrared spectrum: $840 s, 830 s$, $520 s, 510 s$. The ${ }^{31 P}$ NMR $(40.4 \mathrm{MHz})$ gave a doublet at $\delta=-220 \mathrm{ppm}$ from $85 \% \mathrm{H}_{3} \mathrm{PO}_{4}, J_{\mathrm{P}-\mathrm{F}}=1322 \mathrm{cps} ;{ }^{19} \mathrm{~F}$ NMR (94.1 MHz) gave a doublet at $\delta=-20.7 \mathrm{ppm}$ from $\mathrm{F}_{3} \mathrm{CCO}_{2} \mathrm{H}, J_{\mathrm{P}-\mathrm{F}}=1315 \mathrm{cps}$, in good agreement with the ${ }^{31} \mathrm{P}$ spectrum. Vapor pressure data gave $\log \mathrm{P}(\mathrm{mm})=8.17-1500 / T . \mathrm{PF}_{3}$ was obtained from Ozark-Mahoning. All compounds studied were vacuum distilled immediately before use.

NMR data were recorded for neat liquid samples sealed under vacuum in $5 \mathrm{~mm}$ tubes using a Varian Associates HA-100 spectrometer. Infrared spectra were recorded on a Perkin-Elmer model 337 spectrometer.

Dielectric constant determinations were made with a heterodyne beat apparatus ${ }^{7,13}$ operating at $1 \mathrm{MHz}$ over the temperature range $250-303^{\circ} \mathrm{K}$. Capacitance measurements were made over a pressure range of about 60-250 $\mathrm{mm}$ and data $(\Delta C / \Delta P)$ were extrapolated to zero pressure to minimize the effects of nonideal behavior. The relatively low temperatures were chosen to minimize disproportionation of the compounds while providing sufficient pressure to allow good pre- cision in the measurements. The cell and system were calibrated with $\mathrm{NH}_{3}$ and tested with $\mathrm{PF}_{3}$ as described in Ref. 7.

Experimental data are recorded in Table II. The capacitance data were reduced to molar polarization as $P_{T}=\left(760 R T / 3 \times 273.2 C_{0}\right) \times(\Delta C / \Delta P)_{0}$, where $C_{0}$ is the capacitance of the evacuated cell, $213.29 \pm 0.45 \mathrm{pF}$. The slope of $P_{T}$ vs $1 / T$ is then related to the dipole moment as $\mu=0.012812 B$ (Debye method).

\section{ACKNOWLEDGMENT}

We are grateful for a National Science Foundation Fellowship for J.G.M.

* Present address: Department of Chemistry, Utah State University, Logan, Utah.

$\dagger$ Department of Chemistry, University of Utah, Salt Lake City, Utah 84112.

1 J. R. Weaver and R. W. Parry, Inorg. Chem. 5, 703 (1966); G. Kodama, J. R. Weaver, J. LaRochelle, and R. W. Parry, ibid. 5, 710 (1966); J. R. Weaver and R. W. Parry, ibid. 5, 713 (1966); J. R. Weaver and R. W. Parry, ibid. 5, 718 (1966); J. G. Morse and R. W. Parry, J. Chem. Phys. 57, 5365, 5367 (1972) [preceding papers]

2 R. G. Schulman, B. F. Dailey, and C. H. Townes, Phys. Rev. 78, 145 (1950).

${ }^{3}$ A. H. Brittain, J. E. Smith, and R. H. Schwendeman, Inorg. Chem. 11, 39 (1972).

4 U. Grassi, Nuovo Cimento 10, 3 (1933); A. A. Maryott and F. Buckley, Natl. Bur. Std. (U.S.), Circ. No. 537 (1953).

${ }^{B} \mathrm{~K}$. Suenaga and A. Kotera, J. Chem. Soc. Japan Pure Chem. Sec. 70, 116 (1949); Chem. Abstr. 45, 4107c (1951).

${ }^{6}$ M. G. Malone and A. L. Ferguson, J. Chem. Phys. 2, 99 (1934).

${ }_{7}^{7}$ J. G. Morse and R. W. Parry, J. Chem. Phys. 46, 4159 (1967)

8 Y. Morino, K. Kuchitsu, and T. Moritai, Inorg. Chem. 8, 867 (1969).

C. P. Smyth, Dielectric Behavior and Siructure (McGraw-Hill, New York, 1955), pp. 246-47.

${ }^{10}$ R. W. Rudolph, J. G. Morse, and R. W. Parry, Inorg. Chem. 6, 1464 (1967).

11 J. G. Morse, K. Cohn, R. W. Rudolph, and R. W. Parry, Inorg. Synth. 10, 147( 1967).

${ }^{12} \mathrm{Sr}$. M. A. Fleming, Ph.D. dissertation, University of Michigan, Ann Arbor, Michigan, 1962.

${ }^{13}$ J. R. Weaver, S. Shore, and R. W. Parry, J. Chem. Phys. 29, 1 (1958). 